\title{
透水性舗装の都市の熱環境改善効果 に関する実験的研究
}

\author{
北山迪也 $1 \cdot$ 大西有三 2 - 西山 哲 $3 \cdot$ 矢野隆夫 $4 \cdot$ 山本 剛 5 \\ 1学生員 京都大学大学院 工学研究科都市環境工学専攻（†615-8540 京都市西京区京都大学桂） \\ 2正会員 工博, Ph.D 京都大学大学院 教授 工学研究科（干615-8540 京都市西京区京都大学桂） \\ 3正会員 博士(工学) 京都大学大学院 助教授 工学研究科（干615-8540 京都市西京区京都大学桂） \\ 4正会員 博士(工学) 京都大学大学院 技術専門員 工学研究科（三615-8540 京都市西京区京都大学桂) \\ 5正会員 国土交通省近畿地方整備局 近畿技術事務所 所長（干573-0166 枚方市山田池北町11-1）
}

\begin{abstract}
近年ヒートアイランド現象の軽減を目的に，車道に透水性舗装を導入し熱環境を改善しようという試み がなされている，そこで著者らは，車道透水性舗装による都市の熱環境改善効果について検討するため， 必要不可欠なパラメータである蒸発量を定量的に計測する手法の確立を試みると同時に, 一般国道163号 の断面構造を模擬した実物大モデルにおいて夏季に蒸発量, 表面温度および舗装内の温度, 体積含水率等 を計測し, 透水性舗装の熱環境改善効果に関して検証を行ってきた. その結果, 提案した繁発量計測手法 が有用であること，また蒸発が透水性舗装の舗装面温度の低減に寄与していることなどが明らかになった。
\end{abstract}

Key Words : heat island phenomenon, permeable pavement, evaporation, measurement instrument

\section{1. はじめに}

ヒートアイランド現象は都市中心部の気温が郊外に 比べて島状に高くなる現象であり，原因としては人工 地表面の拡大のみならず, 建物の増加・高層化, 人工 排熱の増大等, 様々な要因が複合して生じていると考 えられている1).このようなヒートアイランド現象によ る弊害としては，高温化により暮らしにくくなること にとどまらず, 熱中症の死亡者数の増大を招くこと, 局地的集中豪雨を助長させているなどの報告がなされ ており市民生活の安全を摇るがす危険性を有している. 現在，道路舗装は都市面積の15\%超を占めており， その大部分が不透水性の密粒舗装であり雨水の浸透に よる舗装からの蒸発が期待できない. 舗装から蒸発に よる潜熱が存在しないことにより, 舗装表面温度は高 温となり舗装面からの多量の赤外放射がヒートアイラ ンド現象を助長させていることが指摘されている2). そ こで，ヒートアイランド現象の対策としては，屋上緑 化や緑地の拡大等のほか, 道路面における熱環境対策 が求められている.

このような舗装に対する熱環境改善の要求に伴い, 舗装の熱特性に関して様々な研究がなされている3), 4). 特に近年, 透水性舗装の耐久性に関する研究5), 6が進め
られ，これまで街路樹の育成・地下水の保全等の目的 で歩道に適用されていた透水性舗装を車道に用いる試 み7, 8)が各地で行われている. 車道透水性舗装は本来, 浸透貯留施設として都市における洪水を抑止すること を主な目的として研究がなされてきたが, 熱環境の改 善に関する効果についても期待がなされている.この ような車道透水性舗装の研究は緒に着いたばかりで, 現在のところ, 車道透水性舗装そのものにおいて, 温 度低減効果を論じる上で必要不可欠なパラメータであ る蒸発量を測定し温度低減効果を論じた研究はほとん ど見られない，このことから，車道に透水性舗装が施 工された際にどの程度ヒートアイランド現象の抑制効 果を持つか検討するためには，蒸発量の測定手法を確 立し, 舗装の表面温度や舗装内の温度の計測データの 採取・検討が不可欠といえる.

著者らはヒートアイランド現象の抑制のため, 透水 性舗装からの蒸発量を計測する手法の導入9)試みると ともに，透水性舗装の効果を調査してきた $\left.{ }^{10)}, 11\right)$. 本論 文はこれまで著者らが行ってきたこれらの研究の成果 に新たな知見を加え，報告するものである．まず舗装 面における蒸発量の計測の重要性に触れ, 蒸発量の計 測手法に言及した後, 蒸発がいかに透水性舗装の路面 温度を低減させるかを中心に議論を行う。 


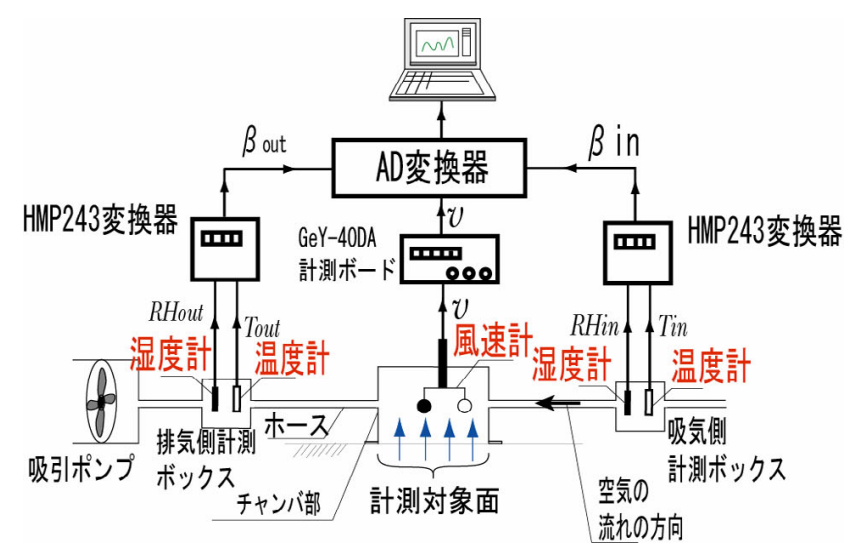

図-1 ベンチレーション法の概要

\section{2. 蒸発量計測手法}

本研究では，透水性舗装の蒸発による温度低減効果 のメカニズムを検証し，ヒートアイランド現象の抑制 に透水性舗装が有効であるのかを調べることを主な目 的としている.このように透水性舗装の効果を検証す るためには, 舗装からの蒸発量を計測することが必要 となる. その理由を以下で述べる.

透水性舗装面での熱収支式は次式(1)のようになる.

$$
R_{n}=H_{P}+G_{P}+l E_{P}
$$

ここに, $R_{n}$ : 正味放射量 $\left[\mathrm{W} / \mathrm{m}^{2}\right], H_{P}$ : 透水性舗装 における顕熱輸送量 $\left[\mathrm{W} / \mathrm{m}^{2}\right], G_{P}$ : 透水性舗装における 地中伝導熱 $\left[\mathrm{W} / \mathrm{m}^{2}\right], l E_{P}$ : 透水性舗装における潜熱輸送 量[W/m²]である.

一方，密粒舗装面では蒸発がないと考えられるため, 熱収支式は以下のようになる。

$$
R_{n}=H_{D}+G_{D}
$$

ここに, $H_{D}$ : 密粒舗装における顕熱輸送量 $\left[\mathrm{W} / \mathrm{m}^{2}\right]$, $G_{D}$ : 密粒舗装における地中伝導熱 $\left[\mathrm{W} / \mathrm{m}^{2}\right]$ である. 以上 の(1), (2)式から潜熱輸送量 $I E$ は次式のように導かれる.

$$
l E_{P}=\left(H_{D}+G_{D}\right)-\left(H_{P}+G_{P}\right)
$$

式(3)は透水性舗装では密粒舗装と比較して潜熱輸送 量 $I E$ だけヒートアイランドの一因である顕熱輸送量と 地中伝導熱の和を減少させるという概念を表している. 従って, 透水性舗装の効果を評価するには蒸発量を定 量的に計測する手法の確立が必要である.

このような蒸発量計測の必要性の高まりにも関わら ず，車道透水性舗装そのものにおける蒸発量計測例は 皆無であるといってよい. 一般的な蒸発量の計測手法 をみると, 農学分野や気象分野では裸地や森林での蒸 発量計測手法の研究が進められてきた。 具体的な手法 としては, ボーエン比法, 渦相関法, シンチレーショ

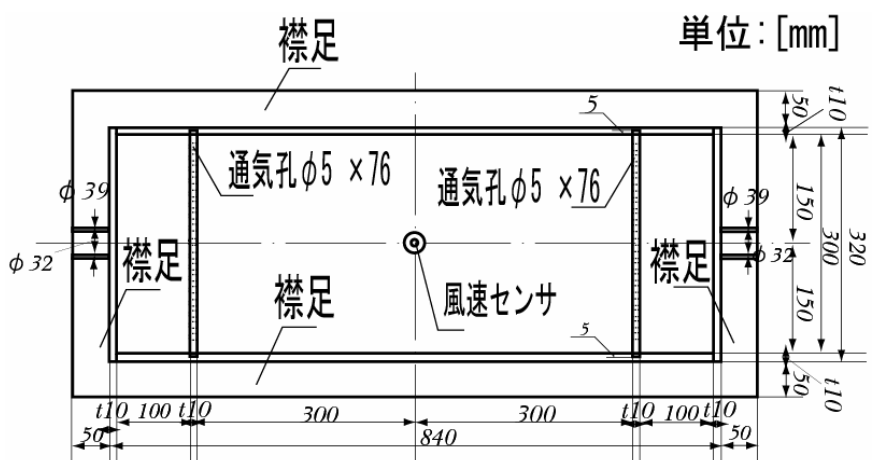

(a) 平面図

単位: [mm]

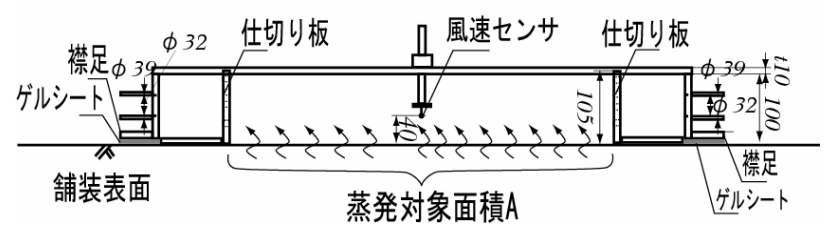

(b) 断面図

図-2 蒸発量計の寸法

ン法などが提案されている。しかしこれらの手法を適 用するには広大な面積を要するため，比較的面積の小 さい舗装面で計測を行うには不向きである，そこで著 者らは，トンネル亀裂からの湧水量の測定等に用いら れているFickの分子拡散による計測手法 ${ }^{12)}$ 用いて透水 性舗装における蒸発量の測定を試みてきた9). しかし, この手法は有風条件下では適用が困難となることが判 明したため，著者らは農学分野等で用いられてきたべ ンチレーション法 ${ }^{13)}{ }^{14)}$ を用いた計測手法を導入し，ヒー トアイランド抑制効果を検証するため蒸発量の計測を 試みている.

\section{(1) 計測の原理}

図-1にベンチレーションチャンバ法による蒸発量計 測システムの概要, 図-2にチャンバ部の平面図および 断面図を示す. ベンチレーション法による蒸発量の計 測の原理は連続式による. 計測の原理を次式(4)に示す.

$$
\beta_{\text {in }} Q \Delta t+A E \Delta t=\beta_{\text {out }} Q \Delta t
$$

ここに， $\beta_{i n}$ は吸気側絶対湿度 $\left[\mathrm{g} / \mathrm{m}^{3}\right], Q$ は流量 $\left[\mathrm{m}^{3} / \mathrm{min}\right], A$ は蒸発面積 $\left[\mathrm{m}^{2}\right], E$ は蒸発量 $\left[\mathrm{g} / \mathrm{m}^{2} / \mathrm{min}\right]$, $\beta_{\text {out }}$ は排気側絶対湿度計測值 $\left[\mathrm{g} / \mathrm{m}^{3}\right]$ ある.

式(4)より蒸発量 $E$ は次式(5)のように導かれる.

$$
E=\frac{Q\left(\beta_{\text {out }}-\beta_{\text {in }}\right)}{A}
$$

以上のように, ベンチレーション法による蒸発量計 測システムは連続式に則っているため，チャンバ部は 蒸気を外部に漏出させない構造とする必要がある。し 


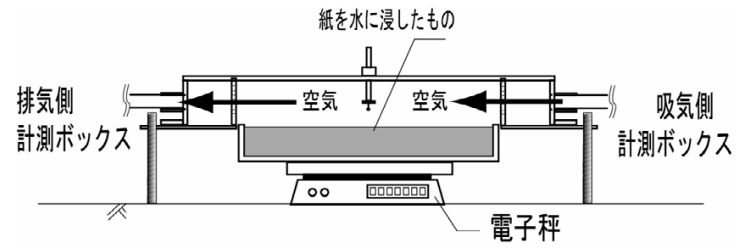

図-3 キャリブレーションの概要

表-1 実験条件

\begin{tabular}{|c||c||c||c|}
\hline & 実験環境 & 最低気温 $\left[{ }^{\circ} \mathrm{C}\right]$ & 最高気温 $\left.{ }^{\circ} \mathrm{C}\right]$ \\
\hline \hline case1 & 室内 & 28 & 28.5 \\
\hline case2 & 室内 & 27.8 & 28.4 \\
\hline case3 & 室内 & 27.6 & 28.3 \\
\hline case4 & 室内 & 27.5 & 28.1 \\
\hline case5 & 野外 & 25.8 & 38.4 \\
\hline case6 & 室内 & 16.7 & 17.2 \\
\hline case7 & 室内 & 15.1 & 16 \\
\hline case8 & 室内 & 16 & 16.4 \\
\hline case9 & 室内 & 16.2 & 16.5 \\
\hline case10 & 室内 & 15.4 & 16.3 \\
\hline case11 & 室内 & 14.8 & 15.6 \\
\hline
\end{tabular}

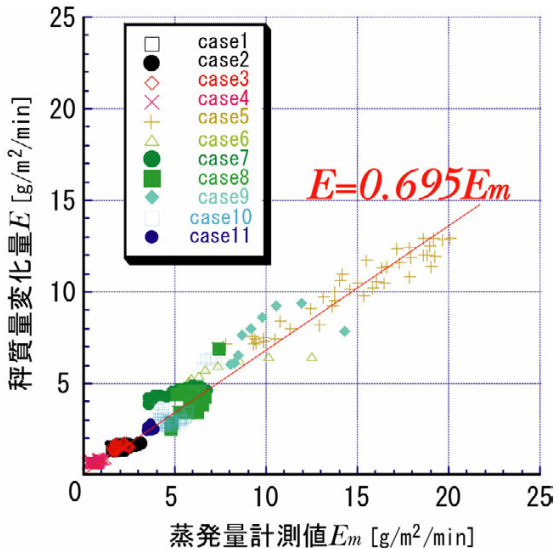

図-4 キャリブレーションの結果

かしながら，透水性舗装の表層や基層は開粒度アスフ アルトからなるため, 単に箱型のチャンバでは蒸気が アスファルトの空隙を通じてチャンバ内部から外部へ と漏れる恐れがある。 そこで，図-2に示すようにチャ ンバ部の端に襟足をつける構造としている.さらに, 弾力性を持つゲルシートをチャンバの襟足部と舗装表 面の間に入れ，気密性を高める工夫をした.

また，本手法は蒸発面をチャンバで覆うため日射や 風速の条件が異なると考えられる。日射に関しては, チャンバを透明のアクリルで作成し蒸発面に注ぐ日射 量をなるべくチャンバ外と変えないようにした。また チャンバ内の風速は図-1に示す吸引ポンプで一定とし, チャンバに設置した風速計で流量を計測している。 た だ，風速はボックス内で不均一と考えられるため, 補 正が必要となる，そこで，風速計の計測值 $V[\mathrm{~m} / \mathrm{sec}]$ に 横断面積 $B\left[\mathrm{~m}^{2}\right]$ を乗じて流量 $Q\left[\mathrm{~m}^{3} / \mathrm{sec}\right]$ を算出する際 に，以下のように補正值 $\alpha$ を導入する.

$$
Q=\alpha v B
$$
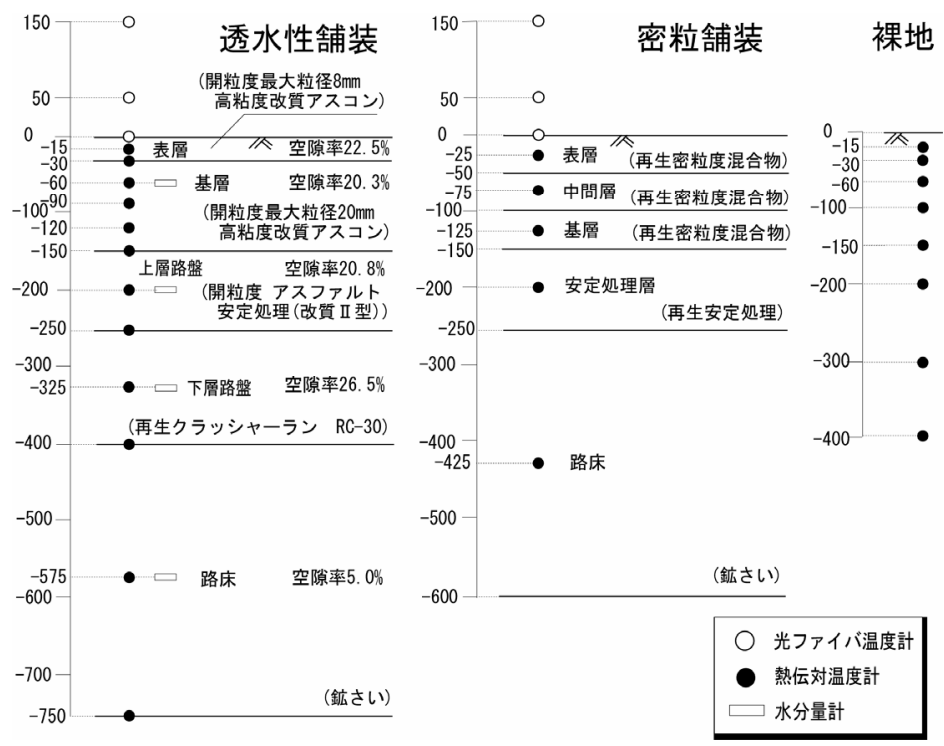

図-5 センサの設置位置

補正值 $\alpha$ の決定方法に関しては次節にて述べる.

\section{（2）定量性の検討}

蒸発量計の計測精度を検証するため, 図-3のように 秤を用いてキャリブレーションを行い定量性を検証し た.

本実験においては, 秤から求めた蒸発量を $E$ $\left[\mathrm{g} / \mathrm{m}^{2} / \mathrm{min}\right]$ とし, 補正值 $\alpha$ は蒸発量 $E$ と蒸発量計から 求めた蒸発量 $E_{m}$ の比とし, 式(7)により補正值を決定 した.

$$
\alpha=E / E_{m}
$$

現場で蒸発量計を用いる際には，気象条件により蒸 発量が大きく変化すると考えられるため，表-1に示す ようにcase1から11まで様々な気温の条件で実験を行っ た. 図-4に各ケースの蒸発量計の計測值 $E_{m}$ と秤の計測 による蒸発量 $E$ の関係を示す。このグラフから $\alpha=0.695$ であることが分かる. $\quad \alpha<1$ となるのは， チャンバ内の中央点における流速に対して壁面近傍や 蒸発面近傍の流速が壁面摩擦により低減されるためで あると推察される。すなわち，チャンバ部の壁面近傍 における流速を中央の流速で過大に評価し流量を算出 しているためと考えられる. 本研究では，この実験の 結果に基づき，次式(8)により蒸発量を算出することと する.

$$
E=\frac{Q\left(\beta_{\text {out }}-\beta_{\text {in }}\right)}{A}=\frac{\alpha v B\left(\beta_{\text {out }}-\beta_{\text {in }}\right)}{A}
$$




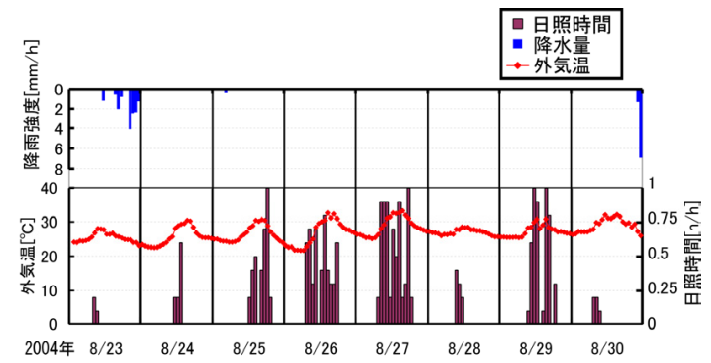

(a) 2004年8月23日 8月30日

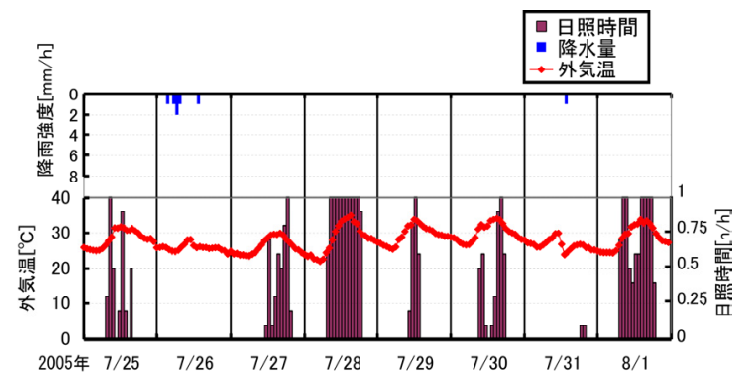

(b) 2005年7月 25日〜8月 1 日

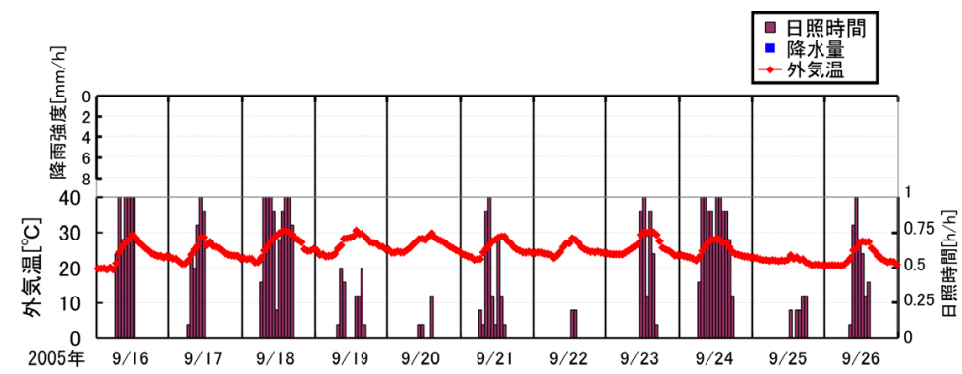

(c) 2005年9月16日～9月26日

図-6 実験期間中の気象

ここで, 本研究で用いたベンチレーションボックス では, $A=0.18\left[\mathrm{~m}^{2}\right], \quad B=0.03\left[\mathrm{~m}^{2}\right]$ としている.

\section{3. 実験施設および計測方法}

\section{(1) 実験施設}

本研究では2004年および2005年の夏季に国土交通省近 畿地方整備局近畿技術事所構内に施工された透水性舗 装モデル実験施設（以下，モデル舗装と呼ぶ）および 同構内の裸地において計測を行い，透水性舗装のヒー トアイランド現象の緩和効果について検討を行った。 本節では，計測を行ったモデル舗装に関して述べる。 なお，2004年度の実験は計測機器の都合からFickの分子 拡散の手法により蒸発量を計測した9)。

モデル舗装の層構造は一般国道163号門真地区で供用 中の透水性舖装試験工区の層構造と一致させてある. このような一般に供用されていないモデル埔装で実験 を行った理由は, 供用中の道路において計測機器を設 置し，蒸発量や舗装表面温度を計測するには交通規制 を行い，一般車両の通行を一時的に禁止する必要があ ったからである. 本研究では実験が長期に及ぶことを

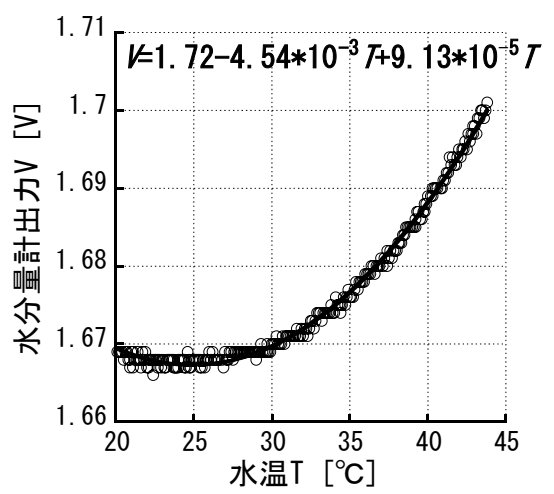

図-7 キャリブレーションの結果

鑑みて，このような交通規制の処置を行うよりも，モ デル舗装を別途施工して実験を行った方が良いとの判 断で，モデル舗装で実験を行うに至った.

舗装内および裸地には図-5のように光ファイバ温度 計, 熱電対温度計, 水分量計を設置している. 舗装構 造および寸法，散水装置等に関しては参考文献8)に譲る.

また，実験期間中の気象データを図-6に示す．この 気象データは気象庁の枚方観測所で計測されたもので ある。

\section{（2）水分量計の温度補正}

本研究では, 水分量計として誘電性土壤水分センサ を用いたが，温度依存性があることが懸念されるため， あらかじめ室内においてキャリブレーション (以下，補 正実験とする)を行った．実験は，センサのプローブ部 を水に完全に浸した状態で水を湯沸器にて徐々に温め, $20^{\circ} \mathrm{C}$ から $50^{\circ} \mathrm{C}$ までの出力を得た. 図一 7 に実験結果を示 す.このグラフから, 温度の上昇に伴い出力が上昇す るという温度依存性が確認される。そこで本研究では, 次式(9)を用いて任意の温度における水分量計の出力を $20^{\circ} \mathrm{C}$ における出力に換算するよう補正を行う.

$$
\begin{aligned}
& V=V_{m}-\Delta V=V_{m}-\left(V_{T}-V_{T=20}\right) \\
& =V_{m}-\left\{a \times(T-20)-b \times\left(T^{2}-20^{2}\right)\right\}
\end{aligned}
$$

ここに, $V$ は補正後の出力值[V]であり, $V_{m}$ は補正 前の出力 $[\mathrm{V}], \Delta V$ は補正值 $[\mathrm{V}], V_{T}$ は補正実験の結果 で $T$ における出力 $[\mathrm{V}], V_{T=20}$ は補正実験の結果で $20^{\circ} \mathrm{C}$ における出力 $[\mathrm{V}], a, b$ は補正実験から得られた定数 でそれぞれ $4.54 \times 10^{-3}, 9.13 \times 10^{-5}$ である.

補正された出力から式(10)を用いて飽和度を算出する.

$$
\theta=c_{1} V+c_{2}
$$

ただし， $c_{1} ， c_{2}$ はセンサ固有の值で定数である. 


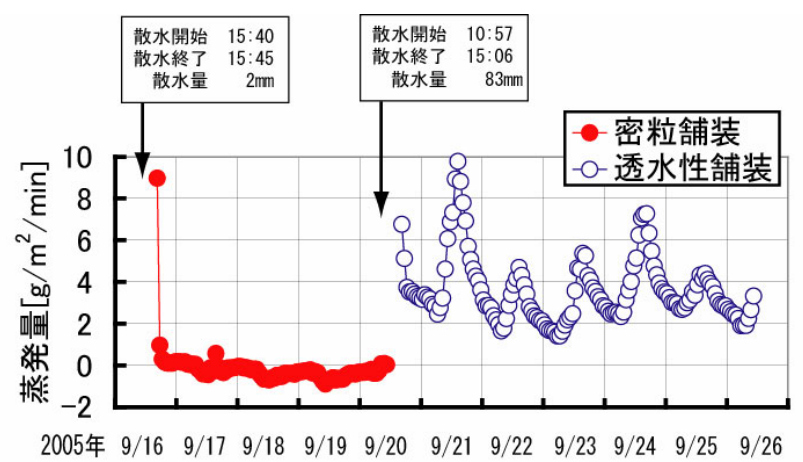

図-8 蒸発量の推移

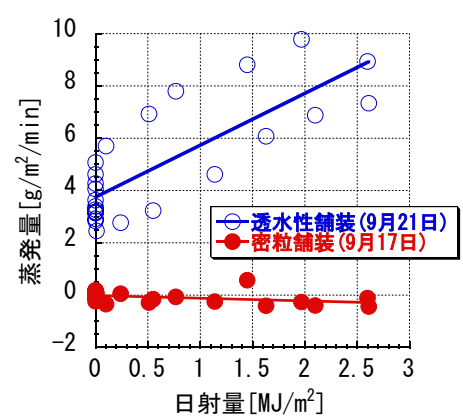

図-9 日射量と蒸発量

\section{4. 実験結果}

(1) 蒸発量

蒸発量測定の重要性については2章で述べた. 本節で は，透水性舗装および密粒舗装における蒸発量の計測 結果について検討を行い, 透水性舗装のヒートアイラ ンド現象を抑制する効果について考察を行う。

図-8に透水性舖装からの蒸発量と密粒舗装からの蒸 発量の経時変化を示寸，なお，蒸発を計測するにあた り, 自然降雨があった後の状態を模擬するため, 蒸発 量の計測開始前に舗装面上に散水を行った. 散水は舗 装内一の降雨浸透が定常状態に落ち着くまで行った. その結果，透水性舗装からの蒸発量を計測する際には 総降雨量 $83 \mathrm{~mm}$ となり, 散水終了時には舗装内に $57 \mathrm{~mm}$ の雨が貯留されていた。一方, 密粒舗装に関しては散 水直後に溢流が始まり舗装内一の雨水の浸透がほぼ見 られなかったため, 総降雨量 $2 \mathrm{~mm}$ で散水を打ち切った. 図-8から, 透水性舗装においては日中に蒸発量が増加 し，夜間に減少する傾向が読み取ることができる，一 方，密粒舗装は散水直後には蒸発量が観測されている が, その後蒸発は見られない。これは密粒舗装がほぼ 水を浸透させない不透水性の密粒度アスファルトから なるため, 舗装内に水が貯留されないことに起因する と考えられる. また, 図-9の日射量と蒸発量の関係よ り, 透水性舗装に関しては日射量が増加すると蒸発量 が増加する傾向が見られる. 一方, 密粒舗装は日射量 が増加しても蒸発量はほぼゼロである。つまり, 密粒 舖装と比較すると透水性舗装は蒸発による潜熱が日射

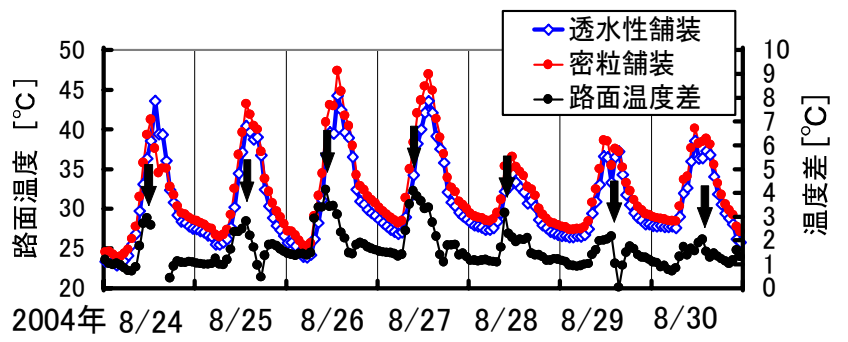

(a) 路面温度

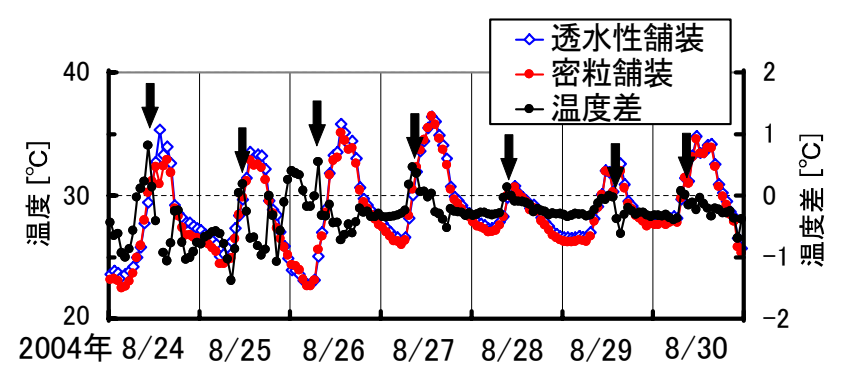

(b) 舖装面上 $5 \mathrm{~cm}$

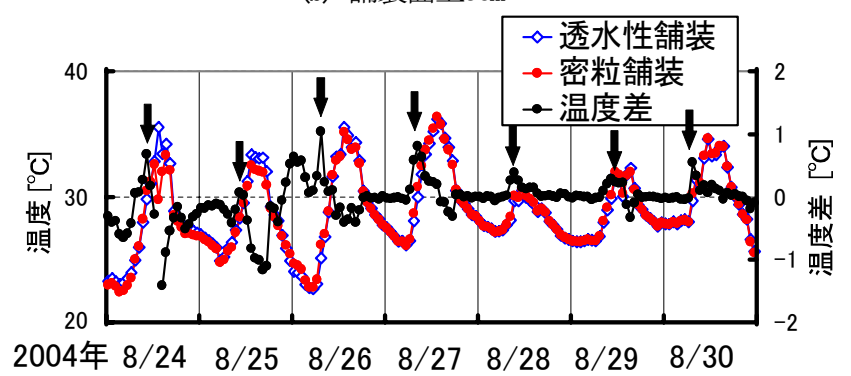

(c) 舖装面上 $15 \mathrm{~cm}$

図-10 透水性舗装と密粒舗装の温度

エネルギーの一部を分担し，式(3)よりヒートアイラン ド現象の原因となる顕熱輸送量および地中伝導熱を減 少させることができると推察される.

\section{（2）舗装温度}

ヒートアイランド現象抑制のためには地表面温度を 低減させることが有効である，本節では，透水性舗装 の路面温度について密粒舗装と比較検討を行う。さら に, 舗装表面温度の低減に関して, 前節で述べた蒸発 がどのように関与するのか検討を行う。

\section{a) 表面温度}

図-10(a) に透水性舗装と密粒舗装の光ファイバ温度 計で測定した地表面温度の経時変化を示す, なお, 図 中の温度差は密粒舗装の温度から透水性舗装の温度を 差し引いた值であり, プラスになると密粒舗装に比べ 透水性舗装の温度が低くなっていることを表す. 図一 10 (a) より, 透水性舗装の方が密粒舗装に比心゙日中に4 度近く温度が低減されていることが分かる。

\section{b）舗装面上の気温}

次に舗装面上の気温の計測結果を検討する. 図一 10 (b) に舗装面上 $5 \mathrm{~cm}$ の温度の経時変化を, 図- 10 (c) に舗 


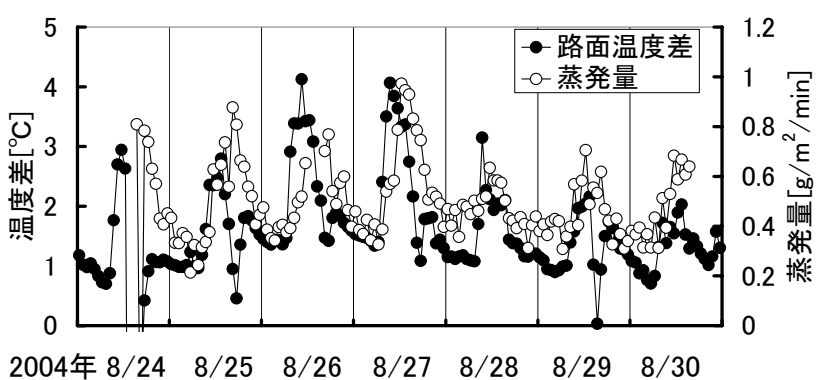

図-11 蒸発量と温度差の経時変化

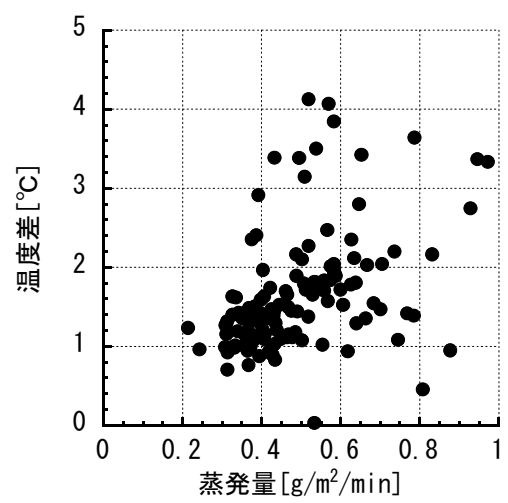

図-12 蒸発量と温度差

装面上15cmの温度の経時変化を示寸. 今, 図-10(a)の 路面温度差が最大となる時間に着目すると, いずれの 日においても舗装表面温度の差が最大となる時間に舗

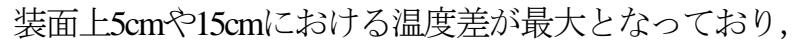
路面温度と舗装面上の温度に関連性が見られる。この ことから, 路面温度における温度の低減が舗装面上 $5 \mathrm{~cm}$, $15 \mathrm{~cm}$ の温度に影響していると考えられる. 寸なわち， 舗装面上の温度を低減させることにより空気の温度を 低減させることができると推察される.

\section{c）温度低減のメカニズム}

図-11 に示した路面温度の差と蒸発量の経時変化より, 日中に蒸発量が増加するに伴って路面温度差が拡大し ている。.また，図-12 の路面温度差と蒸発量の関係より， 路面温度差と蒸発量に相関が見られる. 以上の結果か ら, 透水性舗装の温度低減効果は, 透水性舗装加らの 蒸発が一因として生じていると推察される. 寸なわち, 透水性舗装内に存在する水が蒸気一と相変化し, 潜熱 として熱が舗装から奪われるためであると推察される. 次に透水性舗装加らの蒸発量と気象条件の関係を考 察する. 図-8より，9月24日の蒸発量は22日，23日，25 日よりも多く, 日中に $7.27 \mathrm{~g} / \mathrm{m}^{2} / \mathrm{min} に$ 達している. また， 図-6(c)の日射量を見ると，9月24日は22日や23日，25日 よりも多く, 蒸発量との相関性がある.このことから, 晴天でより多くの日射エネルギーが舗装面上に与えら れると蒸発量が増加する傾向があることが推察される. このことは，曇りの日よりも晴天の日において透水性 舗装が蒸発による温度低減効果を発揮することを意味 し，ヒートアイランド現象の改善に有効であることを

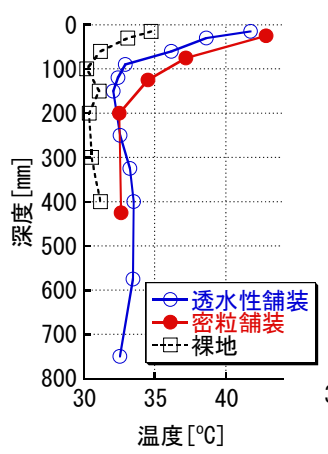

(a) 10:00

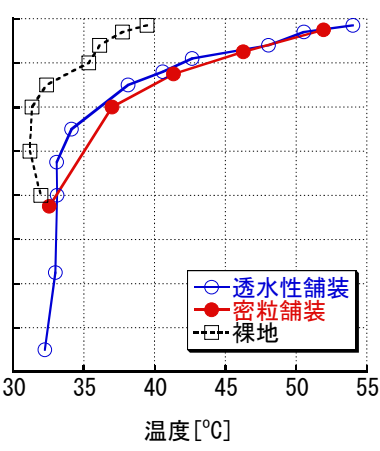

(b) $14: 00$

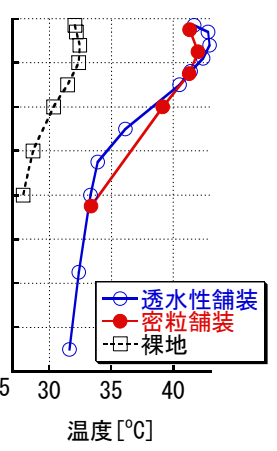

(c) $18: 00$
図-13 舗装内温度 （2005年8月1日）

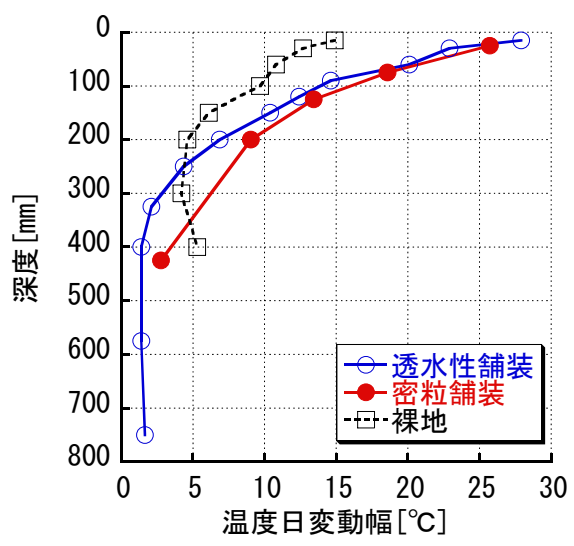

図-14 温度の日変動幅（2005年8月1日）

示唆している.

\section{d）舗装内温度}

前項では，蒸発があることによって密粒舗装に比べて 透水性舗装の温度が低下寸ることを明らかにした。し かし，図-11を見ると，路面温度差がピークとなる時間 が蒸発量の最大となる時間より2時間程度早いことが分 かる，原因としては，透水性舗装の熱特性が密粒舗装 と異なることが考えられる，そこで，透水性舖装，密 粒舗装, 裸地における深さ方向の温度分布について考 察を行い，透水性舗装の熱特性について検討を行う。

図-13に2005年8月1日の透水性舗装と密粒舗装, 裸地 の深度方向の温度分布を, 図-14に温度の日变動幅の深 度方向分布を示す．ただし，日変動幅とは一日の最高 温度から最低温度を差し引いた值とする。 なお, 図一 6(b)に示すように 8月1日は晴天であり, 降雨は記録さ れていない.

まず始めに, 透水性舗装と密粒舗装の加熱時や冷却 時の挙動の違いについて考察を行う. 図-13(a)の10時に おける温度分布を見ると，地表面付近の温度は透水性 舗装の方が密粒舗装に比較すると低くなっている．ま た図-13(c)に示す18時の温度分布を見ると，10時の時点 とは逆に地表面付近の温度は透水性舖装の方が高い.

以上の結果から, 密粒舗装に比べると透水性舖装の 方が同量の熱量に対する温度変化が少ない，つまり熱 容量が大きいと推察される。 このように透水性舗装が 

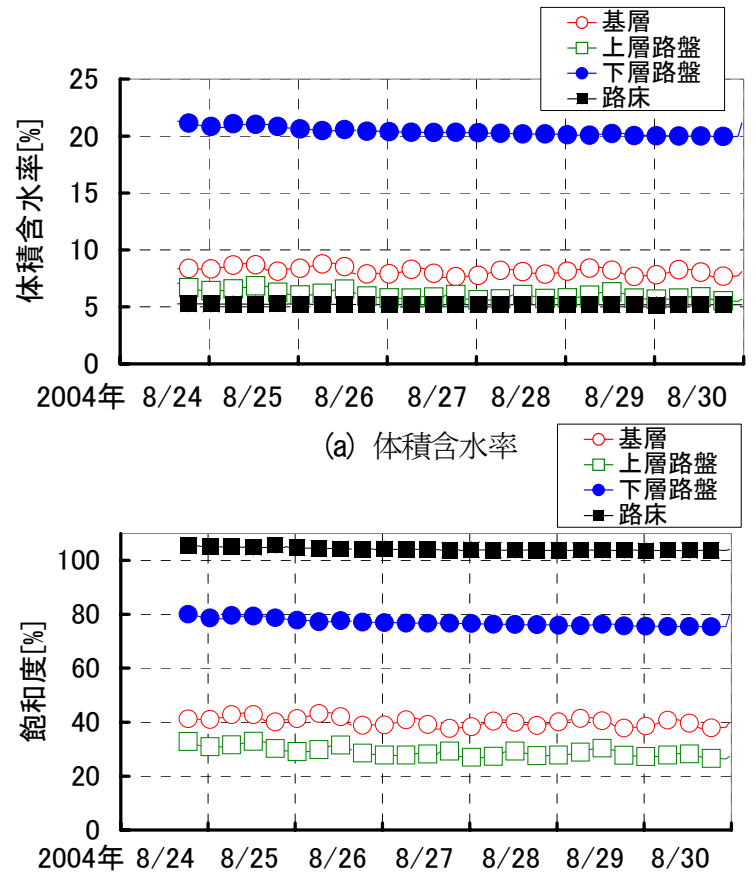

(b) 飽和度

図-15 舗装内の水

密粒舗装に比べて熱容量が大きいと考えられる理由と しては，透水性舗装が熱容量の大きい水を舗装内に貯 留していることが挙げられる. 熱容量が大きいため, 透水性舗装は密粒舗装に比べ温度上昇や温度低下が遅 く, 図-13(a)，(c)のような現象が見られると考えられ る.

次に舗装体と裸地の温度分布を比較し透水性舗装の ヒートアイランド抑制効果について議論する. 図-13よ り，いずれの時間帯においても裸地温度は透水性舗装 や密粒舗装より低下している．また密粒舗装と透水性 舗装を比較すると，18時には表面付近の温度に関して 透水性舗装の温度が密粒舗装よりも高くなっているも のの，いずれの時間においても全体的に透水性舗装の 方が密粒舗装よりも温度が下がっている.

図-14の温度の日変動幅を見ると，0 mmから200 $\mathrm{mm}$ の深 さにおいては密粒舗装と透水性舗装にほとんど差が見 られないものの，密粒舗装に比べると透水性舗装の温 度は全体的に低減され裸地の分布に近づいている。 寸 なわち, 裸地と密粒舗装の差および裸地と透水性舗装 の差を比べると, 密粒舗装と裸地の差より透水性舗装 と裸地の差の方が小さいことが分かる．このことから， 密粒舗装を透水性舗装に変えた場合, 舗装面を自然地 表面の状態に近づけることができると考えられる.

温度が日変動する温度の深さに注目すると, 透水性 舗装は舗装表面から $400 \mathrm{~mm}$ 程度までであり，400 mm以 深はほぼ温度の日変動が見られない。一方, 密粒舗装 は400mm程度においても変動が見られる。このことよ り, 密粒舗装の方が温度変動が生じる領域が

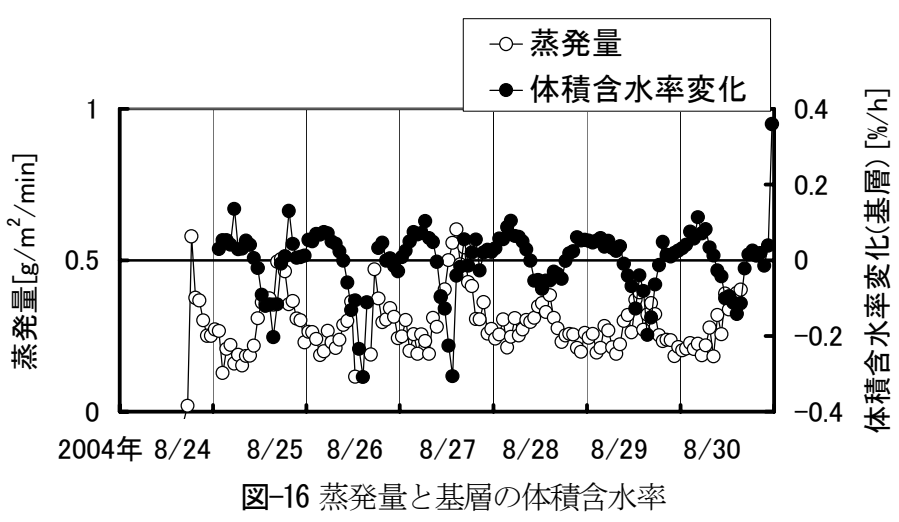

大きいと推察される，つまり，透水性舗装の方が密粒 舗装に比へ熱を溜め込む領域が小さいと考えられる.

以上の結果から，透水性舗装と密粒舗装を比較寸る と，密粒舗装を透水性舖装に変えることにより僅かで はあるが地下の温度分布を裸地のような自然地表面の 分布に近づけることができ，熱環境を改善することが できると推察される.

\section{（3）舗装内の水分挙動}

本研究の目的は透水性舗装の蒸発による温度低減入 カニズムを調べ，透水性舗装の熱環境改善効果を検討 することである. 本節では, 舗装内の水の挙動を把握 寸ることにより, 透水性舖装の温度低減効果のメカニ ズムを検討する，なお，本論文で取り上げる水分量計 の出力值は3(2)で述べたように全てキャリブレーショ ンを行い温度依存性を除外している。

\section{a）舗装内の水}

図-15(a)に舗装中の体積含水率の経時変化を示す. 体積含水率は舗装中の水の絶対的な量を表す指標であ るから，下層路盤に多くの水が保持されていることが 分かる。 これは，下層路盤に用いられている再生クラ ッシャーラン(RC-30)の水分保持特性に起因寸ると推察 される. また, 図-15(b)に示した舗装内の飽和度の推 移から, 路床はほぼ飽和であり, 表層に近づくにつれ て飽和度が低下寸る傾向があることが分かる．路床の 飽和度が高いにも関わらず体積含水率が最も低い理由 は，路床の空隙率が約 $5 \%$ とさいためである．さらに， 図-15から上層路盤と基層に関して飽和度と体積含水率 の值が類似している．これは上層路盤と基層に用いら れている材料が開粒度アスファルトと共通しているこ とによると考えられる. このように舖装内の水の存在 形態は用いられている舗装材料により大きく異なると いうことが推察される。

\section{b) 蒸発と基層の体積含水率}

次に蒸発量と舗装表面近くの基層の体積含水率の関 係について述べる．図-16に1時間あたりの蒸発量と基 層における体積含水率の変化量の変化を示寸。このグ ラフから日中に蒸発が多くなると同時に基層の体積含 


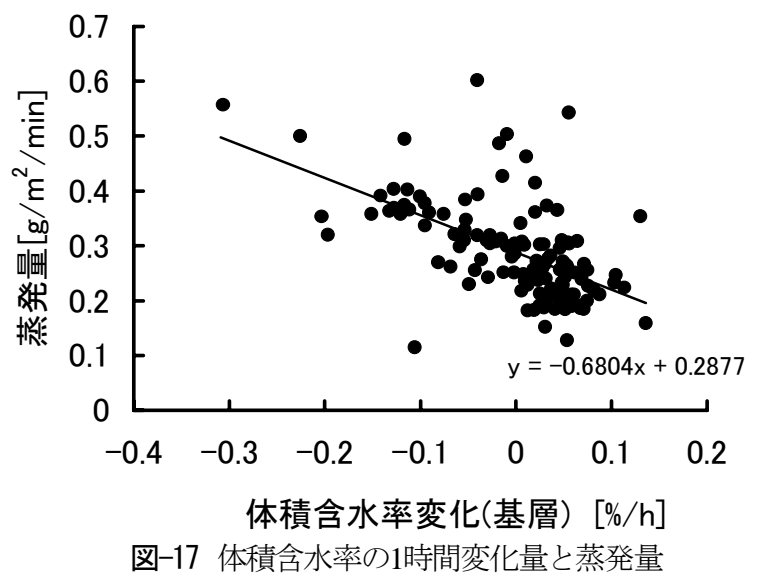

水率が減少する傾向が見られる，さらに，図-17に示し た基層における1時間の体積含水率の変化量と蒸発量の 関係より, 基層の体積含水率が減少すると蒸発量が増 加するという関係が確認される. 従って, 蒸発に基層 の舗装表面の水が消費されていることが推察される.

以上の結果に加え, 図-12から蒸発があることにより透 水性舗装の路面温度が密粒舗装に比心低下寸ると考え られることから, 透水性舗装の表面近くの水の存在が 温度低減効果をもたらす蒸発に関与していると推察さ れる.

\section{c）舗装内の水の挙動}

図-18に示寸舗装内の体積含水率の挙動から，基層や 上層路盤までの深さでは体積含水率が1日のスパンで大 きく変化していることが見て取れる. 今，一日で体積 含水率が最も減少する時間に着目すると，基層に対し， 上層路盤は1，2時間程度遅れ，下層路盤は4時間程度遅 れている，例えば8月25日では，基層が15時20分，上層 路盤は16時, 下層路盤は17時40分に最も体積含水率が 減少している，このように時間遅れを伴いながら，舗 装表面近くの体積含水率の減少が下層路盤などの舗装 深部までに伝達していくということは, 舗装体の表面 のみの水だけではなく, 舗装全体の水が蒸発に関与し ていることを示していると考えられる.

次に，夜間における水の挙動に注目寸ると，昼間と は逆に基層や上層路盤の体積含水率の変化量がプラス, つまり体積含水率が回復している. 図-15(b)の下層路 盤の飽和度を見ると, 単調に減少していることから， 下層路盤から水が一定に供給され, 蒸発が減少する夜 間に基層や上層路盤の含水率が回復すると考えられる.

以上のように地中で水が動き体積含水率が増減を示 す挙動は, 一般土壌においても観測されている ${ }^{15}$. 透水 性舗装が舖装という機能を提供する人工地表面であり ながら，ヒートアイランド現象の抑制に有効な自然地 表面が持つ機能を有することを示唆する結果であると 考えられる。

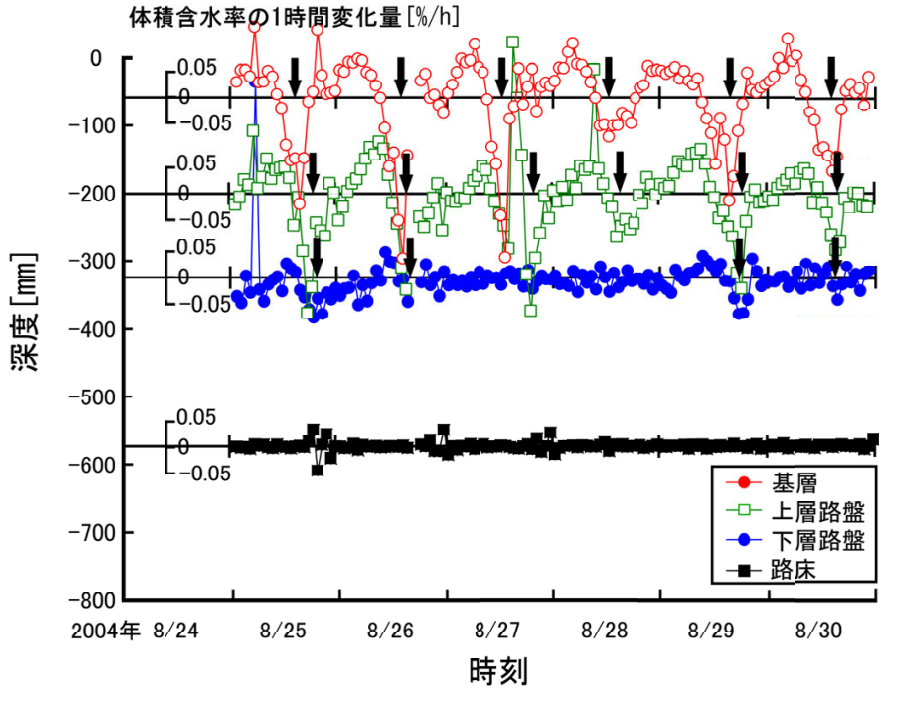

図-18 体積含水率の挙動

\section{5. まとめ}

本研究では，透水性舖装によるヒートアイランド現 象の抑制効果を調べるため, 蒸発量を計測する手法の 確立を試みた。ささに，この蒸発量計測手法を用いて 供用中の透水性舗装断面を模擬したモデル舗装におい て夏季に実験を行い，その効果を検証した.

以下に本研究で得られた主な知見をまとめる.

(1) ベンチレーション法による蒸発量計測手法を導入 し, 透水性舗装の効果を検証する上で必要不可欠 な蒸発量を定量的に測定する手法を提案できた.

（2）提案した蒸発量計測手法を用いて舗装面からの蒸 発を計測し，透水性舗装において蒸発量の増加に 伴い舖装温度が低減するという相関性を明らかに した. 寸なわち, 透水性舗装の表面温度が低下寸 る要因の一つが蒸発であることが分かった.

（3）透水性舗装の表面温度が密粒舗装に比べ日中で最 大 $4^{0} \mathrm{C}$ 程度低減されることや, 舗装上 $5 \mathrm{~cm} や 15 \mathrm{~cm}$ の 空気温度が路面温度の影響を受け, 温度が低下寸 ることが分かった。 よって, 透水性舗装が都市面 積の $15 \%$ 超を占める車道に施工されると, ヒート アイランド現象の改善に効果的であると考えられ る.

（4）舗装内温度の日変動の深さ方向の分布を比較する と, 密粒舗装よりも透水性舗装が裸地に近い分布 を示していることが分かった．よって，密粒舗装 を透水性舗装に変えた場合, 舗装面を自然地表面 の状態に近づけることができると考えられる.

（5）透水性舗装の温度低減効果をもたらす蒸発量と舗 装表面近くの基層の体積含水率に相関性があり, 基層の含水率の低下が下層路盤まで伝達すること が明らかになった。従って, 透水性舗装の熱環境 
改善効果を向上させていく上で，基層等の表面の

みならず舖装全体の水分分布を材料によってどの

ように変えるか検討することが重要である.

\section{参考文献}

1) 文字信貴, 平野高司, 高見晋一, 堀江武, 桜谷哲夫 : 農 学・生態学のための気象環境学, 丸善, pp.140-141, 1997.

2) 浅枝隆, 北原正代, 藤野毅, 和氣亜紀夫 : 加熱された舗装 面上空の大気加熱過程の解析，土木学会論文集 No.467/ II-23, pp.39-47, 1993.

3) 福田萬大, 越川喜考, 辻井豪, 朝枝隆, 藤野毅 : 夏季に 給・散水した保水性舗装の熱環境緩和特性に関寸る実験的 研究，土木学会論文集 No.613/ V42, pp.225-236, 1999.

4) 福田萬大, 深沢邦彦, 荒木美民, 藤野毅, 浅枝隆 : 夏季自 然状態での各種舗装の熱環境緩和特性に関する実験的研究, 土木学会論文集 No.571/V-36，pp.149-158，1997.

5) 鎌田修, 清水忠昭, 伊藤正秀 : 車道透水性舗装の耐久性に 関する研究，土木学会舗装工学論文Vol.10, pp.91-98, 2005.

6) 吉中保, 根本信行, 幸田正裕 : 透水性アスファルトの車道 への適用に関寸る検討, 土木学会舗装工学論文集 Vol.5, pp.47-52, 2000.

7) 荒井進, 大川秀雄, 田口仁, 大竹和彦 : 新潟市における車 道透水性舗装の試み, 舗装 Vol 33 No.3, pp.8-15, 1998.
8) 木下考樹, 和田実, 西山哲, 矢野隆夫 : 車道透水性舗装の 機能評価 一産·学·官の取り組み-, 舗装 Vol.41 No.5, pp.5-9, 2006.

9) 丹原康滋，大西有三，西山哲，矢野隆夫：透水性舗装にお ける蒸発散と熱移動に関する研究, 第 39 回地盤工学研究発 表会公演概要集, pp.2363-2364, 2004.

10）北山迪也，大西有三，西山哲，上原真一，矢野隆夫，青木 一男 : 透水性舗装における熱と水の移動に関する実験的研 究，2005 年土木学会関西支部年次学術講演会，V-36， 2005. 11) 北山迪也，大西有三，西山哲，上原真一，矢野隆夫，和田 実：都市環境保全のための水循環の保全に関する研究，第 54期日本材料学会学術講演会論文集, pp129-130, 2005.

12) 高橋学, 張銘, 李小春 : 地下空洞内の水分移動量を把握す る方法について，地質ニュース 515号，pp.14-23,1997.

13) Mohamed AA, K.Watanabe and U.Kurkawa : Simple method for determining the bare soil resistance to evaporation. Jomal of Groundwater Hydrology, 39(2), pp.97-113.

14) Ali Albed-Rahman $M$, Kunio $W$ and Tai S : Ventilated Chanmber System for Continuous Recording of Both the Evaporation Rate and the Heat Balance at the Bare Soil Surface, Joumal of Groundwater Hydrology, Vol 40-2, pp.185-202, 1998.

15) R.D.Jackson, B.A.Kimball, R.J.Reginato, F.S.Nakayama : Diumal Soil-Water Evaporation : Time-Depth-Flux Patterns, Soil.Sci. Soc. Amer. Proc., Vol37, 1973.

\title{
EXPERIMENTAL STUDY ON THE EFFECTS OF PERMEABLE PAVEMENTS ON THE IMPROVEMENT OF HEAT ENVIRONMENT IN URBAN AREA
}

\author{
Michiya KITAYAMA, Yuzo OHNISHI, Satoshi NISHIYAMA, Takao YANO, \\ and Tsuyoshi YAMAMOTO
}

\begin{abstract}
In these days, some attempts have been made at the improvement of heat environment in urban area by constructing permeable pavements in carriageway area. We have tried to establish the measuring method of evaporation from permeable pavements. And also, we have conducted experiments and have measured evaporation, temperature and volumetric water content on the permeable pavement model, which structure is the same as that of Route 163, in order to examine the effectiveness of permeable pavements. The results show that the proposed method can be useful and evaporation contributes to lower surface temperature of permeable pavements.
\end{abstract}

